Available online at http://journal.stkip-andi-matappa.ac.id/index.php/histogram/index

Histogram: Jurnal Pendidikan Matematika 4(1), 2020 , 17 - 29

\title{
ANALISIS KESALAHAN PADA SISWA KELAS XI DALAM MENGERJAKAN SOAL MATERI MATRIKS
}

\author{
Nofyanti Dewi $^{1^{*}}$, Luvy Sylviana Zanthy ${ }^{2}$ \\ ${ }_{1,2}$ IKIP Siliwangi \\ * Corresponding Author. Email: dewi.nofyanti@gmail.com \\ Received: 27 Januari 2020; Revised: 23 Februari 2020 ; Accepted: 30 Maret 2020
}

\begin{abstract}
ABSTRAK
Penelitian ini memiliki tujuan untuk mendeskripsikan bagaimana kesalahan pada siswa kelas XI dalam mengerjakan soal materi matriks. Penelitian yang termasuk kedalam penelitian deskriptif kualitatif. Subjek dalam penelitian adalah siswa kelas XI MAN di Cimahi yang berjumlah 9 orang. Instrument tes yang diberikan yaitu lima butir soal. Teknik pengumpulan data pada penelitian ini adalah tes. Data yang diperoleh adalah kesalahan yang siswa lakukan dalam menjawab setiap butir soal. Berdasarkan hasil penelitian diperoleh bawah siswa yang menjawab benar pada soal nomor satu sebesar100\%, soal nomor dua sebesar 66,7\%, soal nomor tiga sebesar 10\%, soal nomor empat sebesar 100\%, dan soal nomor lima sebesar 77,8\%. Hasil presentase siswa yang menjawab benar menunjukan bahwa masih banyak kesalahan yang dilakukan siswa. Kesalahan tersebut berada pada soal nomor dua, tiga dan lima. Karena bisa dilihat dari presentase ketiga nomor tersebut memiliki presentase cukup rendah, berbeda dengan soal nomor satu dan empat yang memiliki presentase sangat baik. Kesalahan yang ditemukan pada ketiga nomor diantaranya : 1) kesalahan konsep perkalian matriks, 2) kesalahan dalam perhitungan, 3) kesalahan tidak menuliskan tanda operasi, 4) kesalahan konsep, dan 5) kesalahan kecerobohan. Kesalahan ini disebabkan siswa lupa materi, kecorobohan, kurang memperhatikan informasi yang dari soal dan tidak telitinya siswa dalam mengerjakan soal.
\end{abstract}

Kata Kunci: analisis kesalahan, matematika, materi matriks

\section{ABSTRACT}

The goal of this research is to describe how wrong all of the students in the sophomores have been in solving matrix material. The method of this research is qualitative descriptive research. The subject in this research is XI grade of MAN CIMAHI is 9 person. The instrument of the test was given the five grains of matter. The data-collection of this technique is a test. The data was obtained is a student's fault in answering every questions. Based on the results was obtained by the undergraduates who get the right answers on the number is one problem is $100 \%$, the problem of number two is $66.7 \%$, the problem of number three is $10 \%$, the problem of number four is $100 \%$, and the problem of number five at $77.8 \%$. The results of this research is student do the presentation that gave the correct answer show there are many mistakes of the students. The fault show in problem number two, three and five. Because it evidenced in third percentage that the number has a fairly low percentage, in contrast to the number one and four that have a very good presentation. The Errors found in all three numbers such as : 1) matrix multiplication errors, 2) errors in calculation, 3) errors did not mark operations, 4) draft errors, and 5) discretionary errors. The mistake was caused by students forgetting the material, demolition, lacking interest and not studying in their problem of studens.

Keywords: errors analysis, mathematics, matrix materials

Copyright $($ C 2020, THE AUTHOR (S). This article distributed under the CC-BY-SA-license. 


\section{Histogram: Jurnal Pendidikan Matematika, 4(1), 2020- 18 Nofyanti Dewi ${ }^{1}$, Luvy Sylviana Zanthy ${ }^{2}$}

How to Cite: Dewi, N., \& Zanthy, L, S. (2020). Analisis Kesalahan Pada Siswa Kelas Xi Dalam Mengerjakan Soal Materi Matriks. Histogram: Jurnal Pendidikan Matematika, 4(1), 17 - 29, doi: http://dx.doi.org/10.31100/histogram.v4i1.513

Permalink/DOI: http://dx.doi.org/10.31100/histogram.v4i1.513

\section{PENDAHULUAN}

Di era milenial ini yang penuh dengan berbagai macam persaingan, cara berpikir mempunyai peran penting dalam menyelesaikan masalah dalam kehidupan. Dalam hal ini pendidikan sangat diperlukan. Karena pendidikan merupakan kegiatan yang harus ditempuh setiap individu. Hal tersebut sejalan dengan apa yang dikemukan oleh (Siti Chotimah, Ramdhani, Bernard, \& Akbar, 2018) yaitu pendidikan merupakan dasarnya dari pembelajaran yang harus setiap individu tempuh baik secara pendidikan formal maupun pendidikan non formal.Pendidikan juga sebagai salah satu kebutuhan sepanjang hayat (Chotimah, 2015). Dimana pendidikan ini sebagai upaya meningkatkan kualitas dan mengembangkan potensi diri, serta mengembangkan ilmu pengetahuan dan teknologi, untuk itu setiap individu wajib mengenyam pendidikan. Pendidikan yang kualitas sangat diperlukan oleh setiap individu sebagai upaya untuk mengembangkan sumber daya dalam dirinya.

Dalam dunia pendidikan banyak masalah yang dihadapi, salah satunya masalah pendidikan yang di hadapi oleh bangsa Indonesia. Masalahnya berupa rendahnya mutu pendidikan yang ada di Indonesia, hal inilah yang menjadikan upaya peningkatan kualitas dari pendidikan menjadi hal yang di fokuskan dalam pembangunan bangsa Indonesia. Hasil dari tes Trend In International Matematics and Sciense Study (TIMSS), lembaga yang mengukur dan membandingkan berbagai kemampuan matematis siswa-siswi antar Negara, bahwasanya penguasaan matematika siswa berada pada tingkat 8 . Pada tahun 1999 bangsa Indonesia menduduki peringkat ke 32 dari 38 Negara yang diteilti. Tahun 2003 ke 36 dari 45 yang di teliti, pada tahun 2007 bangsa Indonesia menduduki peringkat ke 41 dari 48 negara yang di teliti. Rata-rata skor yang diperoleh siswa-siswi Indonesia adalah sebesar 397. Skor ini masih jauh dari yang diharapkan, sebab yang seharusnya dicapai sesuai skor Internasional yaitu 500. Ini yang menyebabkan kualitas dari pendidikan Indonesia masih rendah dan memerlukan upaya untuk menangani dan meningkatkannya (Setiawan, 2015). Untuk meningkatkan kualitas pendidikan sekolah dituntut untuk bisa menyiapkan peserta didik agar memiliki berbagai kemampuan, yang nantinya bisa digunakan dalam berbagai 


\section{Histogram: Jurnal Pendidikan Matematika, 4(1), 2020- 19 Nofyanti Dewi ${ }^{1}$, Luvy Sylviana Zanthy ${ }^{2}$}

hal yang diperlukan oleh peserta didik, sehingga peserta didik mempunyai kualitas dan mampu untuk bersaing dengan orang lain.

Dalam pendidikan sangatlah banyak bidang ilmu. Salah satu diantaranya adalah ilmu matematika. Matematika merupakan pelajaran yang dijumpai di sekolah dan dikehidupan sehari-hari. Sejalan dengan beberapa pendapat yang pertama yang dikemukakan oleh (Aripin \& Purwasih, 2017) menyatakan bahwa matematika merupakan bagian penting dalam berbagai bidang ilmu pengetahuan. Matematika merupakan ilmu eksakta yang memerlukan berpikir kreatif dari pada hapalan, hal tersebut bisa dilihat dari sudut pengklasifikasian dari bidang ilmu pengetahuan. Peserta didik harus mampu dalam menguasai konsep pokok bahasan, sehingga peserta didik mampu memahami dan berpikir kreatif dalam memecahkan masalah yang dihadapi peserta didik. Adapun pendapat lain yang dikemukakan oleh (Zanthy, 2016) bahwasanya matematika merupakan salah satu mata pelajaran yang penting, sebab menuntut kemampuan berpikir seseorang dalam menyelesesaikan masalah kehidupan dan dapat disajikan kedalam model matematika. Selain itu matematika ilmu yang mempelajari pola keturunan, tentang struktur yang terorganisasi (Komalasari, 2019). Oleh karena itu, matematika masuk dalam segi kehidupan manusia dimulai dari yang paling sederhana ke hal yang paling sulit.

Dalam matematika banyak hal yang akan kita dapatkan dan matematikapun memiliki fungsi sesuai dengan yang dikemukakan oleh Soedjadi (Alimuddin, 2009) yaitu sebagai sarana untuk membagun nalar dari siswa. Dengan mempelajari metematika diharapkan siswa dapat memiliki nalar dan berpikir secara kritis, logis, analitis dan kreatif. Hal inilah yang menjadikan alasan matematika itu penting dipelajari sekolah dari berbagai jenis jenjang pendidikan, sesuai yang dikemukakan oleh (Ruseffendi, 2010) bahwa matematika itu ratunya dari ilmu yang mempunyai arti pelayan dari berbagai bidang ilmu yang ada.Karena itulah matematika penting untuk dipelajari, sesuai apa yang dikemukakan oleh Cockroft (Abdurrahman, 2003) bahwa matematika penting diajarkan diberbagai jenjang karena: 1) digunakan dalam kehidupan. 2) digunakan dalam bidang ilmu lainnya. 3) sebagai sarana komunikasi. 4) digunakan untuk memberikan berbagai informasi. 5) bisa meningkatkan kemampuan dalam berpikir logis, ketelitian dan kesadaran ruang. 6) digunakan dalam memecahkan masalah yang menantang.

Cara bernalar dan berpikir siswa secara kritis, logis, analitis dan kreatif tentunya dapat meningkat jika diasah dengan memperbanyak mengerjakan soal-soal matematika. Akan tetapi, sebagai manusia biasa siswa pasti pernah melakukan kesalahan dalam ISSN: 2549-6700(print), ISSN: 2549-6719(online) 


\section{Histogram: Jurnal Pendidikan Matematika, 4(1), 2020- 20 Nofyanti Dewi ${ }^{1}$, Luvy Sylviana Zanthy ${ }^{2}$}

mengerjakan soal-soal matematika. Masalah yang perlu menjadi perhatian adalah seberapa banyak kesalahan yang dapat dilakukan siswa dalam menyelesaikan soal-soal matematika.

Kesalahan-kesalahan umum yang sering dilakukan oleh siswa dalam menyelesaikan soal-soal matematika menurut Newman (Fausan, Sagita, \& Sukayasa, 2019) dibedakan menjadi lima tipe kesalahan yaitu 1) reading error (kesalahan membaca), 2) comprehension error (kesalahan memahami), (3) transformation error (kesalahan dalam transformasi), (4) skills error (kesalahan dalam keterampilan ), (5) notation error (kesalahan pada notasi). Pendapat (Wulandari \& Resta, 2018) yaitu kesalahan yang dapat dilakukan siswa saat menyelesaikan soal matematika diantaranya adalah 1) kesalahan konsep, 2) kesalahan prinsip, 3) kesalahan operasi, 4) kesalahan karena kecerobohan.

Kesalahan merupakan hal yang wajar dilakukan, namun apabila kesalahan yang dilakukan cukup banyak dan berkelanjutan, maka diperlukan penanganan (Wahbi \& Anwar, 2015). Penyebab dari kesalahan yang dilakukan siswa yakini kurangnya pemahaman dari konsep materi yang telah dipelajari, kurang memahami bahasa matematika, siswa yang keliru dalam penggunaan rumus matematika dan ketidaktelitian siswa dalam perhitungan matematika (Badaruddin, Kadir, \& Anggo, 2016).

Matriks merupakan salah satu cabang dari materi aljabar yang diajarkan disekolah menengah atas atau sekolah menengah kejuruan. Materi matriks ini merupakan salah satu sub pelajaran matematika yang cukup sulit. Hal tersebut terbukti dari hasil observasi dan wawancara yang dilakukan (Fausan et al., 2019) terhadap guru pelajaran matematika dibeberapa sekolah bahwasanya materi matriks merupakan materi yang dianggap tidak mudah bagi siswa, saat pembelajaran guru sering melakukan kuis atau tes untuk mengetahui apa masih ada siswa yag melakukan kesalahan atau tidak ternyata saat hasil tes diperoleh masih ada siswa yang melakukan kesalahan pada perkalian matriks, pemahaman konsep, kesalahan rumus, dan kesalahan dalam menghitung nilai matriks dari kesalahankesalahan yang terjadi mengakibatkan pekerjaan siswa kurang maksimal dan prestasi belajarpun menjadi menurun. Penelitian yang relevan dengan penelitian ini adalah hasil penelitian (Fausan et al., 2019) dalam menyelesaikan soal matriks diperoleh bahwa kesalahan siswa adalah kesalahan tidak memahami konsep rumus perkalian matriks, kesalahan konsep perkalian matriks, kesalahan konsep invers matriks, kesalahan konsep adjoin, kesalahan tidak menuliskan tanda operasi, dan kesalahan dalam melakukan perhitungan. Adanya keterkaitan antara penelitian ini dengan penelitian sebelumnya yaitu 


\section{Histogram: Jurnal Pendidikan Matematika, 4(1), 2020- 21 Nofyanti Dewi ${ }^{1}$, Luvy Sylviana Zanthy ${ }^{2}$}

terkait kesalahan yang dilakukan siswa, fokus peneliti dalam penelitian ini adalah menganalisis kesalahan yang dilakukan siswa dalm mengerjakan soal materi matriks.

Berdasarkan uraian diatas, penulis tertarik untuk melakukan analisis kesalahan pada siswa kelas XI dalam menngerjakan soal materi matriks di Kota Cimahi dengan harapan penelitian ini dapat bermanfaat bagi siapapun yang membaca, untuk mengetahui kesalahan yang dilakukan siswa dalam mengerjakan soal.

\section{METODE PENELITIAN}

Penelitian ini termasuk kedalam penelitian deskriptif kualitatif, yang memiliki tujuan untuk mendeskripsikan bagaimana kesalahan pada siswa dalam mengerjakan soal materi matriks. Subyek penelitian ini adalah siswa yang telah mendapatkan materi matriks yaitu siswa kelas XI MAN di Cimahi yang berjumlah 9 orang siswa. Pengambilan jumlah siswa tersebut merupakan saran yang diberikan oleh guru mata pelajaran disekolah tersebut. penelitian ini yang menjadi fokus adalah penyelesaian soal matematika materi matriks. Adapun instrument tes yang diberikan yaitu lima butir soal, dengan instrument yang digunakan telah diperiksa oleh dua orang pembimbing dan dinyatakan bahwa instrument tes tersebut valid. Teknik pengumpulan data pada penelitian ini adalah tes. Data yang diperoleh dari tes adalah kesalahan yang siswa lakukan dalam menjawab setiap butir soal.

Instrumen tes yang digunakan dalam penelitian ini berindikator sebagai berikut : 1) Mampu menerangkan secara verbal mengenai apa yang telah dicapai; 2) Mampu mengklarifikasikan obyek tertentu yang sesuai dengan konsepnya; 3) Mampu menyajikan konsep kedalam berbagai bentuk representasi; 4) Mampu mengembangkan konsep yang telah dipelajari dengan mengaplikasikan konsep atau algoritma dalam pemecahan masalah;

5) Siswa mampu menyajikan model matematika dari suatu konteks masalah yang nyata berkaitan dengan matriks.

\section{HASIL DAN PEMBAHASAN}

\section{A. Hasil Penelitian}

Berdasarkan hasil pekerjaan siswa dengan diberikan lima butir soal uraian, bahwa siswa berusaha menyelesaikannya dengan baik, meskipun terjadinya kesalahan dalam menyelesaikannya. Secara umum pengerjaan siswa terhadap soal tes ditemukan ada siswa yang masih mengingat dan memahami materi matriks dan ada pula yang sudah lupa akan 


\section{Histogram: Jurnal Pendidikan Matematika, 4(1), 2020- 22 Nofyanti Dewi ${ }^{1}$, Luvy Sylviana Zanthy ${ }^{2}$}

cara pengerjaan soal. Siswa juga terlihat ada yang mengalami sedikit kesalahan, salah satu contohnya adalah kesalahan dalam operasi.

Selanjutnya dilakukan analisis untuk mengetahui jenis-jenis kesalahan apa saja yang dilakukan oleh siswa dan persentase dari masing-masing kesalahan yang dilakukan siswa. Berikut ini tabel presentase siswa yang menjawab soal dengan benar dari masingmasing soal.

Tabel 1. Presentase Siswa Yang Menjawab Benar

\begin{tabular}{clcc}
\hline Soal & \multicolumn{1}{c}{ Indikator } & Presentase \\
\hline 1 & Mampu menerangkan secara verbal mengenai apa yang telah & $100 \%$ \\
& dicapai & & \\
\hline 2 & Mampu mengklarifikasikan obyek tertentu yang sesuai & $66,7 \%$ \\
& dengan konsepnya & & \\
\hline 3 & Mampu menyajikan konsep kedalam berbagai bentuk & \\
& representasi & \\
\hline 4 & Mampu mengembangkan konsep yang telah dipelajari dengan & $100 \%$ \\
& mengaplikasikan konsep atau algoritma dalam pemecahan & \\
& masalah & \\
\hline 5 & Siswa mampu menyajikan model matematika dari suatu & $77,8 \%$ \\
& konteks masalah yang nyata berkaitan dengan matriks
\end{tabular}

(Sumber: Data Primer, Tahun: 2019)

Dari Tabel 1 diperoleh presentase siswa yang menjawab benar paling sedikit terdapat pada soal nomor 3 yaitu sebesar 10\%. Pada indikator mampu menyajikan konsep kedalam berbagai bentuk representasi tergolong sangat rendah sebesar 90\% untuk siswa yang tidak bisa menjawab dengan benar. Kebanyakan siswa kesulitan dalam melakukan representasi. Menurut (Farkhan \& Firmansyah, 2020) representasi merupakan proses dimana sebuah objek ditangkap oleh indra seseorang, lalu masuk ke dalam akal untuk diproses yang hasilnya adalah sebuah konsep atau ide dengan bahasa akan disampaikan kembali. Akan tetapi, menurut pendapat (Rangkuti, 2013) representasi bukan hanya menunjuk pada hasil atau produk yang diwujudkan dalam kontruksi baru dan berbeda tetapi proses pikir yang dilakukan seseorang untuk dapat menangkap dan mamahami konsep, operasi, dan hubungan matematik dari suatu kontruksi baru. Salah satu hasil penelitian (Tasman, Yenti, \& Heriyanti, 2016) menyatakan bahwa kesalahan dalam 
Histogram: Jurnal Pendidikan Matematika, 4(1), 2020- 23

Nofyanti Dewi ${ }^{1}$, Luvy Sylviana Zanthy ${ }^{2}$

representasi matematis salah satunya karena kurangnya kemampuan siswa dalam mentransformasi soal dengan faktor yaitu lupa cara untuk menyelesaikan soal dan kurangnya pemahaman terhadap soal. Untuk mengetahui kesalahan apa saja yang dilakukan oleh siswa dengan melakukan analisis dari masing-masing soal.

\section{Analisis soal nomor 1}

Butir soal pertama dengan indikator mampu menerangkan secara verbal mengenai apa yang telah dicapai.

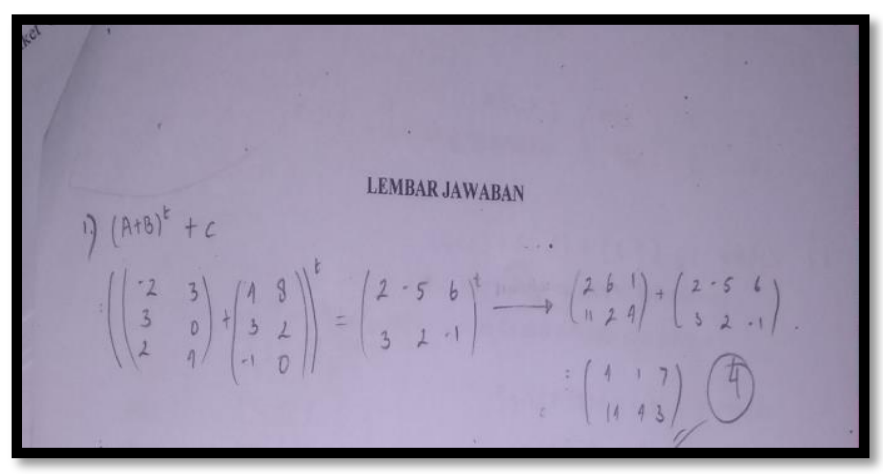

Gambar 1. Jawaban Siswa AD Pada Soal Nomor 1

Pada soal nomor satu semua siswa menjawab benar sebesar $100 \%$, salah satu contoh jawaban siswa AG sesuai dengan apa yang ditanyakan pada soal. Siswa AG menguasai konsep dari apa yang ditanyakan pada soal nomor satu, begitupun pada siswa lainnya yang jawabannya sama seperti jawaban milik siswa AG. Kesulitan siswa yang terjadi pada soal nomor satu ini kemungkinan rendah, karena semua siswa dapat mengerjakan soalnya dengan benar tanpa ada kesalahan langkah satupun.

\section{Analisis soal nomor 2}

Butir soal kedua dengan indikator mampu mengklarifikasikan obyek tertentu yang sesuai dengan konsepnya.

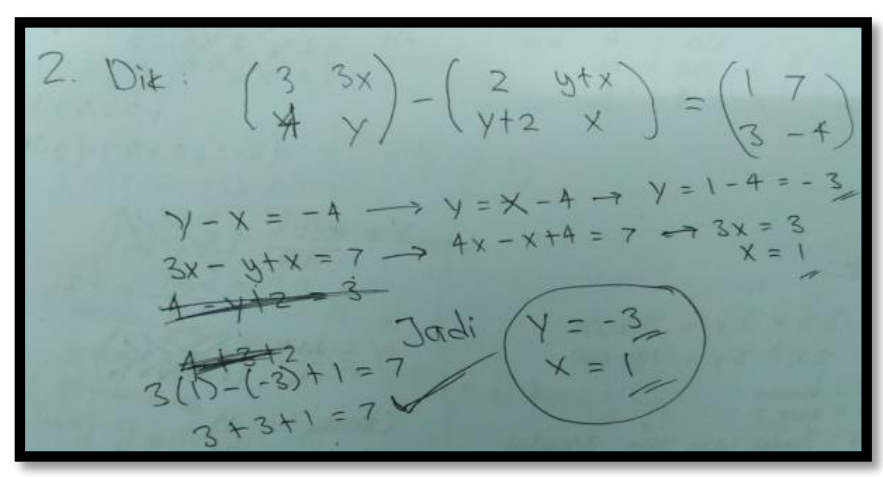

ISSN: 2549-6700(print), ISSN: 2549-6719(online) 
Gambar 2. Kesalahan Jawaban Siswa BD Pada Soal Nomor 2

Kesalahan yang dilakukan siswa dalam menjawab soal nomor 2 sebesar 33,3\%, kesalahan yang terjadi kurangnya penguasaan konsep materi disebabkan kurang pahamnya siswa dalam menyelesaikan soal. Jawaban yang seharusnya siswa melakukan pengurangan terhadap kedua matriks tersebut dengan hasil $\left[\begin{array}{cc}1 & 2 x-y \\ 2-y & y-x\end{array}\right]=\left[\begin{array}{cc}1 & 7 \\ 3 & -4\end{array}\right]$, dari hasil tersebut siswa harusnya mengambil $2-\mathrm{y}=3$ untuk mencari nilai y didapat $\mathrm{y}=-1$ dan untuk mencari nilai $\mathrm{x}$ siswa harusnya mengambil $y-x=-4$ dengan melakukan subtitusi pada nilai y yang sudah diketahui pada $-1-x=-4$ didapat $x=3$. Dengan cara mengurangkan terlebih dahulu soal dapat memudahkan siswa dalam mengerjakan. Dari hasil yang diperoleh siswa penyebab terjadinya kesalahan diantaranya penguasaan konsep dikarena lupa, ceroboh, tidak teliti dan penguasaan konsep yang cukup lemah.

\section{Analisis soal nomor 3}

Butir soal ketiga dengan indikator mampu menyajikan konsep kedalam berbagai bentuk representasi.

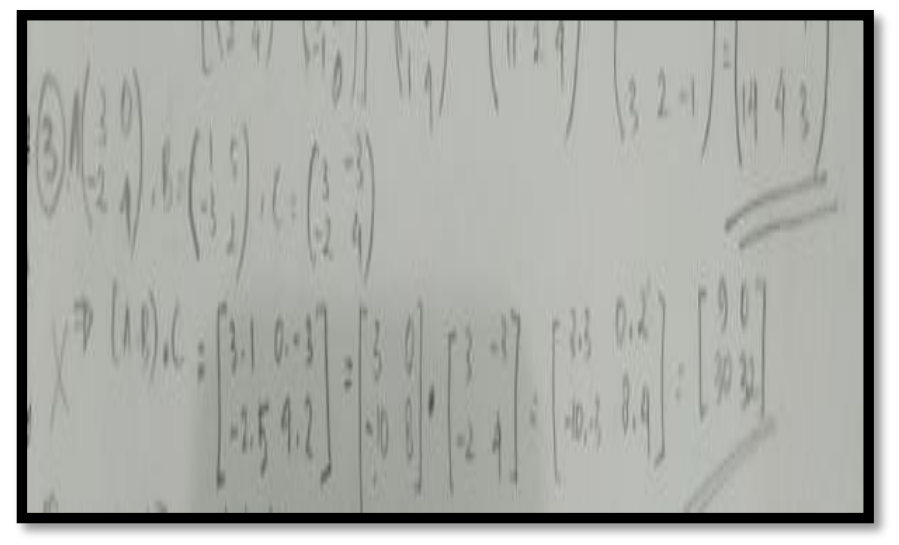

Gambar 3. Kesalahan Jawaban Siswa NS Pada Soal Nomor 3

Kesalahan yang dilakukan siswa dalam menjawab soal nomor 3 sebesar 90\%, berdasarkan jawaban siswa yang melakukan kesalahan pada konsep perkalian matriks yaitu mengalikan baris dengan kolom. Seharusnya jawaban konsep perkalian matriks yang benar adalah baris pertama pada matriks A dikali dengan kolom pertama pada matriks B. Selain itu siswa juga melakukan kesalahan saat perhitungan yaitu operasi perkalian dan tidak menuliskannya tanda operasi seperti tanda negatif. Kesalahan penulisan tanda operasi terjadi saat siswa melakukan perkalian matriks pada baris satu kolom dua dengan matriks 
Histogram: Jurnal Pendidikan Matematika, 4(1), 2020- 25

Nofyanti Dewi ${ }^{1}$, Luvy Sylviana Zanthy ${ }^{2}$

baris dua kolom satu. Kendala yang dihadapi siswa pada soal nomor 3 adalah kurang telitinya siswa dalam mengerjakan soal.

\section{Analisis soal nomor 4}

Butir soal keempat dengan indikator mampu mengembangkan konsep yang telah dipelajari dengan mengaplikasikan konsep atau algoritma dalam pemecahan masalah.

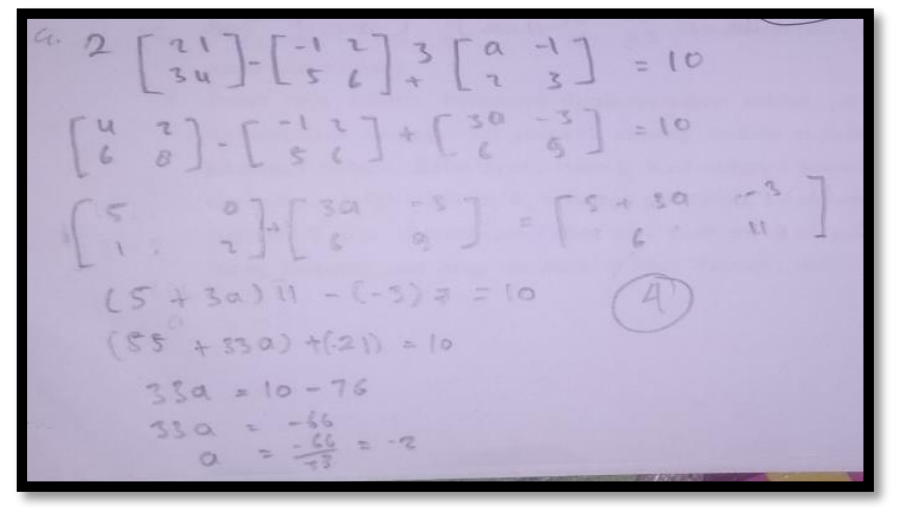

Gambar 4. Jawaban Siswa SL Pada Soal Nomor 4

Semua siswa dapat menjawab dengan benar sebesar $100 \%$, salah satunya contoh jawaban siswa SL yang sesuai dengan apa yang ditanyakan pada soal, yakni siswa mampu menyelesaikan soal secara benar dan tepat. Siswa SL dilihat menguasai konsep dari apa yang ditanyakan pada soal. Kesulitan yang dialami siswa SL sangatlah rendah, karena siswa dapat mengerjakan soalnya dengan benar tanpa ada kesalahan langkah satupun begitupun dengan siswa lainnya menjawab sama seperti langkah siswa SL.

\section{Analisis soal nomor 5}

Butir soal kelima dengan indikator Siswa mampu menyajikan model matematika dari suatu konteks masalah yang nyata berkaitan dengan matriks.

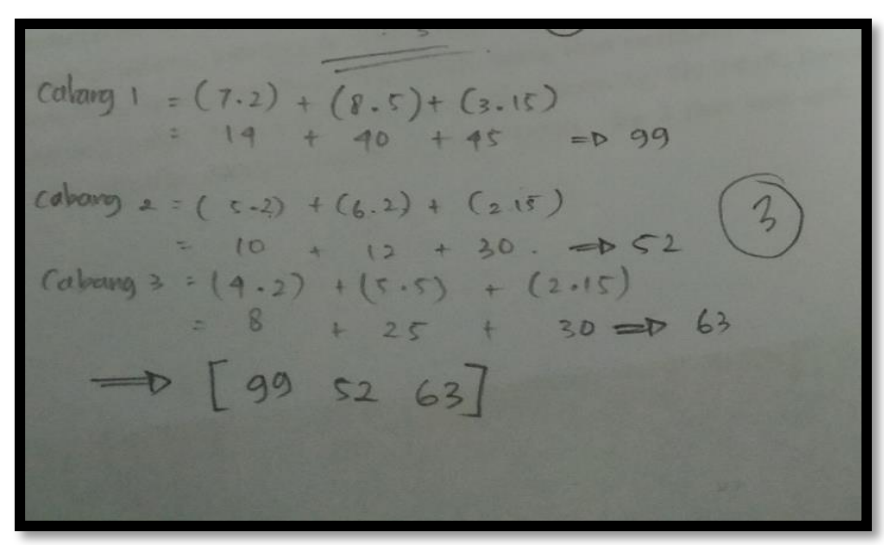

Gambar 5. Kesalahan Jawaban Siswa NS Pada Soal Nomor 5 ISSN: 2549-6700(print), ISSN: 2549-6719(online) 
Kesalahan yang dilakukan oleh siswa dalam menjawab soal nomor 5 sebesar $22,2 \%$, kesalahan terdapatpada konsep perhitungan. Selain perhitungan siswapun kurang teliti dalam mengerjakan soal. Bisa dilihat dari gambar 5, yang seharusnya pada cabang kedua siswa memasukan angka $(5 \times 2)+(6 \times 5)+(2 \times 15)=70$. tetapi siswa memperoleh hasil yang berbeda. Kurang telitinya pada soal nomor 5 yang menyebabkan terjadinya kesalahan.

\section{B. Pembahasan}

Berdasarkan dari hasil analisis terhadap masing-masing soal tersebut siswa melakukan kesalahan. Siswa melakukan kesalahan pada konsep untuk mencari nilai $\mathrm{x}$ dan y, kesalahan konsep perkalian matriks, kesalahan dalam penulisan tanda operasi dan kesalahan pada perhitungan. Kesalahan konsep untuk mencari nilai $x$ dan $y$ ini yang disebabkan siswa tidak paham akan cara penyelesaian terhadap soal, sejalan dengan pendapat (Utami, 2012) bahwa kesalahan konsep yang dilakukan siswa disebabkan ketidaktahuan dan ketidakpahaman siswa akan konsep, sehingga banyak konsep yang dipahami siswa secara keliru.

Kesalahan pada konsep perkalian matriks yang dilakukan oleh siswa NS yaitu kesalahan perkalian baris dengan kolom. Seharusnya perkalian antara baris pertama dengan kolom pertama lalu perkalian baris pertama dengan kolom dua ang akan menghasilkan baris pertama pada matriks baru, tapi siswa NS tidak melakukan itu. Hal itu lah yang menjadikan siswa NS melakukan kesalahan. Kesalahan tersebut merupakan kekeliru dan lupa akan cara penyelesaian dalam soal, sejalan dengan pendapat (Ramlah, Bennu, \& Paloloang, 2016) kesalahan konsep perkalian matriks dikarenakan kekeliruan yang dilakukan siswa, kebanyakan siswa berfikir bahwasanya suatu matriks dapat dikalikan hanya jika ordo dari matriks yang akan dikalikan itu sama, sehingga ketika menemukan matriks yang memiliki ordo yang berbeda siswa langsung salah ketika mengalikan entri-entrinya.

Kesalahan tidak menuliskannya tanda operasi juga dilakukan oleh siswa NS. Hal tersebut dilakukannya saat menuliskan jawaban pada soal nomor 3 saat mengalikan angka pada baris satu kolom dua dengan anggota matriks baris dua kolom satu. Kesalahan tersebut merupakan kesalahan fakta yang dilakukan siswa. Hal tersebut sesuai dengan yang dikemukakan (Wulandari \& Resta, 2018) bahwasanya kesalahan dalam penulisan dan kesalahan dan tanda operasi merupakan kesalahan fakta.

Selanjutnya kesalahan pada perhitungan yang dilakukan siswa terdapat pada operasinya yakni kesalahan yang terjadi pada soal nomor 5 yang seharusnya hasil perkalian ISSN: 2549-6700(print), ISSN: 2549-6719(online) 
pada cabang kedua angka $(5 \times 2)+(6 \times 5)+(2 \times 15)=70$, tetapi siswa salah memasukan angka pada cabang kedua sehingga terjadi kesalahan saat perkalian dan hasilpun berbeda. Hal tersebut sejalan dengan pendapat (Utami, 2012) bahwa kesalahan hitung yaitu kesalahan melakukan operasi hitung dalam matematika seperti menjumlahkan, mengurangkan, mengali dan membagi. Salah satu hasil penelitian (Imelda, Yusmin, \& Suratman, 2014) bahwa kesalahan siswa dalam melakukan operasi hitung berhubungan dengan konsep operasi hitung dan kecerobohan siswa dalam memperhatikan operasi hitung seperti salah menulis tanda operasi hitung dan menempatkan hasil operasi hitung. Adapun yang menjadikan kesalahan tersebut disebabkan kecerobahan siswa dalem menyelesaikan soal matriks

\section{KESIMPULAN DAN SARAN}

\section{A. Kesimpulan}

Berdasarkan hasil dan pembahasan yang telah dijelaskan diatas, dapat disimpulkan bahwa kesalahan yang dilakukan: 1) kesalahan konsep perkalian matriks; 2) kesalahan dalam melakukan perhitungan; 3) kesalahan tidak menuliskan tanda operasi; 4) kesalahan konsep; 5) kesalahan kecorobohan. Kesalahan ini terjadi karena ketidaktelitian dalam mengerjakan dan kurang memperhatikan informasi yang diberikan oleh soal.

\section{B. Saran}

Saran yang dapat peneliti berikan untuk mengurangi kesalahan siswa pada materi matriks yaitu : 1) Bagi guru, sebaiknya memberikan banyak latihan soal materi matriks agar siswa bisa mengevaluasi ketidakpahaman dalam materi matriks; 2) Bagi Siswa, hendaknya banyak melakukan latihan mengerjakan soal untuk lebih meningkatkan kemampuan pemahamannya dan meningkatkan keterampilan berhitung agar dalam menyelesaikan soal yang diberikan siswa tidak melakukan kesalahan kembali pada proses pembelajaran, serta konsep yang dimiliki siswa bertambah banyak dan tidak lagi terjadi kesalahan dalam melakukan perhitungan; 3) Bagi peneliti lain, agar mengembangkan penelitian analisis kesalahan siswa dengan rujukan teori kesalahan dari banyak ahli, menambahkan jenis-jenis kesalahan dan faktor penyebab dari kesahan tersebut secara lebih rinci dan mendalam. 


\section{DAFTAR PUSTAKA}

Abdurrahman, M. (2003). Pendidikan Bagi Anak Berkesulitan Belajar. Jakarta: Rineka Cipta.

Alimuddin. (2009). Menumbuh Kembangkan Kemampuan Berpikir Kreatif Siswa Melalui Tugas- Tugas Pemecahan Masalah. Prosiding Seminar Nasional Penelitian , Pendidikan Dan Penerapan MIPA, Yogyakarta, UNY.

Aripin, U., \& Purwasih, R. (2017). Penerapan Pembelajaran Berbasis Alternative Solutions Worksheet untuk Meningkatkan Kemampuan Berpikir Kreatif Matematik. Jurnal Pendidikan Matematika FKIP Univ.Muhammadiyah Metro, 6(2), 225-233.

Badaruddin, Kadir, \& Anggo, M. (2016). Analisis Kesalahan dalam Menyelesaikan SoalSoal Operasi Hitung Pecahan pada Siswa Kelas VII SMP Negeri 10 Kendari. Jurnal Penelitian Pendidikan Matematika, 4(2), 43-56.

Chotimah, S. (2015). Upaya Meningkatkan Kemampuan Komunikasi Matematik Siswa SMP di Kota Bandung dengan Pendekatan Realistic Mathematics Educations pada Siswa SMP di Kota Bandung. Jurnal Ilmiah STKIP Siliwangi Bandung, 9, 26-32.

Chotimah, S., Ramdhani, F. A., Bernard, M., \& Akbar, P. (2018). Pengaruh Pendekatan Model-Eliciting Activities Terhadap Kemampuan Berpikir Kritis Matematik Siswa. Journal On Education, 01(02), 68-77.

Farkhan, N. N., \& Firmansyah, D. (2020). Analisis Kemampuan Representasi Matematis Siswa SMA Pada Materi Matriks. Prosiding Sesiomadika, 2(4), 971-979.

Fausan, Sagita, G., \& Sukayasa. (2019). Profil Kesalahan Siswa dalam Menyelesaikan Soal Matriks Berdasarkan Jenis Kelamin di SMA Negeri 7 Palu. AKSIOMA, 08(02).

Imelda, M., Yusmin, E., \& Suratman, D. (2014). Profil kesalahan siswa dalam menyelesaikan soal operasi hitung campuran bilangan bulat di smp. Jurnal Pendidikan Dan Pembelajaran Khatulistiwa, 3(2), 1-13.

Komalasari, L. I. (2019). Analisis Kemampuan Siswa dan Guru SMK dalam Menyelesaikan Masalah Matematika. Histogram, 3(2), 189-198.

Ramlah, Bennu, S., \& Paloloang, B. (2016). Analisis Kesalahan Siswa dalam Menyelesaikan Soal Penjumlahan dan Pengurangan Pecahan di Kelas VII SMPN Model Terpadu Madani. Jurnal Ilmiah Pendidikan Matematika, 1(2), 182-194.

Rangkuti, A. R. (2013). Representasi Matematis. Logaritma, I(02), 49-61.

Ruseffendi, E. T. (2010). Dasar-Dasar Penelitian Pendidikan dan Bidang Non-Eksakta Lainnya.Bandung. (Tarsito, Ed.). Bandung.

Setiawan, W. (2015). Meningkatkan Kemampuan Berpikir Kritis Matematis Siswa SMP dengan Menggunakan Model Penemuan Terbimbing. Jurnal Ilmiah UPT P2M STKIP Siliwangi, 2(1).

Tasman, F., Yenti, I. N., \& Heriyanti, S. (2016). Analisis kesalahan transformasi soal pada kemampuan representasi matematis secara simbolik. EKSAKTA, 2, 24-30.

Utami, W. . (2012). Identitas Kesulitan Siswa dalam Menyelesaikan Persoalan Matematika yang Berkaitan dengan Pecahan di Kelas VII SMP Negeri 3 Ngaglik Sleman Tahun Ajaran2011/2012. E-Jurnal Universitas Negeri Yogyakarta, [Online](Tersedia:http// journal.student.uny.ac.id/jurnal/artikel/471/43/180 [19 Januari 2020]).

Wahbi, A., \& Anwar, B. (2015). Analisis Kesalahan Siswa dalam Menyelesaikan Soal Faktorisasi Suku Aljabar Ditinjau dari Objek Matematika pada Siswa Kelas VIII SMP Negeri 15 Kendari. Jurnal Penelitian Pendidikan Matematika, 3(1).

Wulandari, T., \& Resta, E. L. (2018). Analisis kesalahan siswa dalam menyelesaikan soal pada materi lingkaran. Jurnal Pendidikan Tambusai, 2, 1693-1697. 
Histogram: Jurnal Pendidikan Matematika, 4(1), 2020- 29

Nofyanti Dewi ${ }^{1}$, Luvy Sylviana Zanthy ${ }^{2}$

Zanthy, L. S. (2016). Pengaruh Motivasi Belajar ditinjau dari Latar Belakang Pilihan Jurusan Terhadap Kemampuan Berpikir Kritis Mahasiswa di STKIP Siliwangi Bandung. Jurnal Teori Dan Riset Matematika (TEOREMA) Vol., l(1). 